\title{
Some observations on Calvin research with special reference to South Africa
}

\section{P. Coertzen}

Department of Ecclesiology

Faculty of Theology

University of Stellenbosch

STELLENBOSCH

\begin{abstract}
The aim of this article is to take a general look at contemporary Calvin research, referring especially to what happened in this respect within more or less the last twenty years; more specifically this article will concentrate on developments within the last ten years. The results of the findings are specifically related to Calvin research in South Africa. The article can, in a sense, also be seen as an altempt to convey some of the results of the latest International Calvin Research Congress of 1990 to the Calvin research community in South Africa. In this endeavour firstly some general remarks are made with regard to Calvin research; secondly current trends in Calvin research are focused upon; the third heading indicates research needs; a fourth paragraph outlines material research aids available to Calvin researchers and in a concluding paragraph a few specific remarks with regard to Calvin research in South Africa are made.
\end{abstract}

\section{An overview of general trends in Calvin research}

Right from the beginning of the twentieth century there has been some interest in Calvin; which did not necessarily mean that Calvin has always been correctly understood. Already in 1929 the Dutch theologian Klaas Schilder wrote about "een verblijdende belangstelling voor Calvyn, die allerminst vrucht is van een begrijpen van Calvijn ... waarin zo heel veel wat van Calvijn weinig of niet weten wil, zich toch op Calvijn beroept" (cf. Schilder, 1981:69). Interest in Calvin also does not necessarily mean that Calvin has always been appreciated. In 1986 William Klempa found enough evidence to include the following passage in his paper "The Image of John Calvin in Recent Research", read at the Colloquium.

If anything, Calvin continues to suffer from bad press in both popular and more scholarly literature. He is still pictured as the Genevan dictator ruling a submissive population with a rod of iron, a kind of theological wet blanket and the apotheosis of a pious kill-joy (K'lempa, 1987:343). 
However, it must also be stated that during the past two decades there has definitely been evidence of a resurgence of interest in Calvin, an interest which has not only been sustained but which has also gained momentum. The result of this is inter alia that the image of Calvin is coming into clearer focus and bears the characteristics of one of the truly great scholars of the sixteenth century. In this respect Harris Harbison (1987:146) wrote the following:

... Calvin preserved closer touch with all the major thougth-forms of the past than either Erasmus or Luther, each of whom was more genuinely revolutionary in his own way. He did so because he was more objective in his approach to scholastic, juristic, and humanistic learning, because he could absorb their methods without subscribing to their spirit and swallowing their content, and because he was more catholic in his intellectual tastes.

The interest in Calvin throughout the twentieth century is reflected inter alia in the fact that he is probably, apart from perhaps Luther, the theologian in the history of the Christian Church about whom the most twentieth century biographies have been written. This trend started with the monumental seven volume work of Emile Doumergue in 1899-1927 and has continued in various languages right up to our time with one of the latest being John Calvin. A Sixteenth Century Portrait, a biography written by William Bouwsma. Currently there are probably more than a dozen Lives of Calvin in print.

Most probably it was the founding of the European Congress on Calvin Research in 1974 in Amsterdam which led John Leith in 1977 to state that studies on Calvin had been gaining momentum again. Not that studies on Calvin had not been undertaken before that time, but a definite direction and aim for Calvin studies was stimulated by this Congress. Of that Congress, attended by about fourty reseachers from Europe, A. Wolters wrote: "To my mind, that year and that Congress mark the beginning of a new era in Calvin studies ..." (Wolters, 1987: 350). Its proceedings was published in 1976 in Neukirchen in the volume Calvinus Theologus, a title with which Meianchton honoured Calvin. It was also decided to invite researchers from all over the world to attend the next Calvin Research Congress.

The next Congress, which in fact was the first International Calvin Research Congress, was held four years later in 1978 - also in Amsterdam. From all over the world, except Australia, reseachers convened in Amsterdam. From the beginning it was decided to go about it in an elitair fashion and invite only one hundred experienced researchers and a few of the younger generation researchers to partake in the congress. From the start it was also decided to read only three papers per day with ample time for intensive discussion. It was also the aim of the congress that the chosen themes of the Congresses should stimulate as much research 
as possible. Right from the outset it was found that these International Calvin Research Congresses did not only stimulate various regional Congresses but there was also an urgency among researchers to get to know the writings of Calvin, to absorb themselves in the thoughts of Calvin - and to gain profit from their research for godliness in general and the church of Jesus Christ. The proceedings of the 1978 Congress was published by Kok in Kampen under the title Calvinus Ecclesiae Doctor (Neuser, 1982:87-88).

The second International Calvin Research Congress was held in Genève in 1982. The proceedings of this Congress was published in 1984 under the title Calvinus Ecclesiae Genevensis Custos (Neuser, 1984). New to this Congress was the inauguration of smaller working groups - groups in which new research in a preliminary stage could be presented and where themes for new research could also be introduced. The next international Congress was held in Debrecen, Hungary from the 25th to the 28th of August 1986, the theme being Calvinus servus Christi. The proceedings of this Congress was published in 1988 by the Pressabteilung des Ráday-Kollegiums in Budapest (cf. Neuser, 1988). The most recent International Congress - the fifth Quadrennial Congress, was hosted by the Calvin Theological Seminary, Grand Rapids Michigan and was held from 20-23 August 1990. The theme of this congress was Calvinus Sacrae Scripturae Professor. The proceedings of this Congress is yet to be published.

While the so-called International Congress on Calvin Research continued to meet every four years, since 1978 various regional or territorial congresses and colloquia on Calvin research have come into existence. In 1980 the Calvinkongress Mittelosteuropa met for the first time in Debrecen (Hungary), in 1984 in the then East Berlin and in 1988 in Vienna. The proceedings of the 1984 meeting was published under the title Immigration und Emigration - die calvinistische Einwanderung und Auswanderung in Mitteleuropa. Beitrage des II. Kongresses für Calvinforschung in Mittel- und Osteuropa $198+$ (edited by J. Langhoff and J. Rogge).

In the same year, 1980, the first meeting of the African Congress for Calvin Research met in Pretoria; this was followed by a meeting in Potchefstroom (1984) and a meeting in Stellenbosch (1988). The papers of the 1980 meeting were published in 1982 under the title Calvinus Reformator. His Contribution to Theology, Church and Society, while the papers of the second congress were published as John Calvin's Institutes. His Opus Magnum. Proceedings of the Second South African Congress for Calvin Research 1984. The papers of the third congress were published under the title: Calvin-France-South Africa (Pont, 1990) This third South African Congress held in 1988, the year of the tercentenary celebrations of the coming of the Huguenots to South Africa in 1688, had as theme the relationship between Calvin and the Huguenots. Prof. Neuser in his article 
"Het werk van de Calvijncongressen en hun toekomstige taken en doelen" (Neuser, 1990:87-91) reports the 1980 Congress in Pretoria as the "African Congress for Calvin Research" while in the mentioned publication it is cited as "the First South African Congress for Calvin Research". Perhaps this disparity with regard to the scope of the Calvin research in Africa is one of the issues which have to be addressed in future. It is a well known fact that some aspects of Calvin research have been going on for instance in Egypt, with a publication of the Institutes in Arabic. Certainly other reseachers in Africa have also engaged in research on Calvin and the Reformation and the question is whether they should not be identified and invited to participate in future (South) African congresses on Calvin research.

In 1987 the East Asian Calvin Congress met for the first time in Kobe, Japan, with participants from Japan, South Korea and Taiwan as well as a few participants from the Phillipines.

In Northem America more than one regional research congress have come into being. At Davidson in the United States the Colloquium on Calvin Studies meets every two years. Some of the papers read at the Colloquia have been published i.a.: Calvin Studies II (Leith \& Raynal, 1986). Calvin Studies III (Leith, 1986). Calvin Studies IV (Leith \& Johnson, 1986). The Calvin Theological Seminary in Grand Rapids, Michigan also hosts research congresses on a regular basis. The first was held in 1976 with the papers presented under the title Renaissance, Reformation, Resurgence (1976). A fifth Colloquium of this institution was held in 1985 with the papers published also in 1987 under the title Calvin and Christian Ethics (1985). In Canada Calvin research has been going on as well. In 1986 the Faculty of Religious Studies at the McGill University in Montreal hosted an international Calvin Symposium. The proceedings was published in 1987 under the title: In Honor of John Calvin 1509-64. Papers from the 1986 International Calvin Symposium McGill University.

To my mind it is quite relevant for reseachers in South Africa to take note of the various schools of Calvin interpretation which have been discerned. In a chapter entitled "Calvin's Critique of Calvinism" in his book The Dawn of the Reformation, Heiko Oberman (1986:259-268) distinguishes six schools of interpretation of Calvin namely:

* The classical interpretation. According to this school "valid theology is the reiteration of the position described - and hence prescribed - by Calvin" (cf. Doumergue, Jean Calvin 7 vol., Lausanne 1910-1917).

* The confessional interpretation, also called the Calvinist, Protestant Scholastic interpretation by Henry van der Goot (1975). Within this school of interpretation Calvin is viewed through the eyes of the Westminster Confession and the Heidelberg Confession with the result that Scripture and predes- 
tination are seen to be the foci of his thought (cf. B.B. Warfield, Calvin and Calvinism and Calvin and the Reformation).

* The neo-orthodox school according to whom God's revelation is only grasped in Christ through Scripture, reflected in predestination as the covenant of grace (Barth, 1936). As exponents of this school of thought the work of the following researchers should also be kept in mind: W. Niesel (The Theology of Calvin), T.H.L. Parker (The Doctrine of the Knowledge of God: A Study in the Theology of John Calvin), F. Wendel (Calvin: the Origins and Development of His Religious Thought), E. Dowey (The Knowledge of God in Calvin's Theology) K. Barth \& E. Brumner (Natural Theo$\log y)$.

* A fourth school of interpretation which Oberman discerns is what he calls the Dutch School as especially reflected in the thought of Abraham Kuyper and Herman Bavinck, but later also in the works of Herman Dooyeweerd and G. Berkouwer. This school stressed the sovereignty of God over all cultural manifestations of life; hence it includes a theology of society, of the state, of politics - although this theology can not be labelled as 'theocratic' in the strict sense of the word

* In the fifth place the so-called anti-orthodox interpretation presents another school of interpretation. Representatives of this method of interpretation usually build their views "upon some mythical and some historical elements. Calvin is described as the enemy of culture and of research; as the murderer of Servetus, and the manager of police-controlled Geneva" (Oberman, 1986: 260).

* The Historical school. Initially this school was against all forms of 'theological' interpretation of Calvin. This school usually tries to abstain from the debate concening the right application of Calvin's thoughts, with the result that it has very little patience with any form of a confessional interpretation of Calvin. According to Oberman this school has done much to answer the theses implied in the anti-orthodox view.

Oberman is of opinion that all six schools are represented in South Africa with a very substantial and lasting contribution with regard to the last school formed by the late Dr. Andre Hugo in his work Calvijn en Seneca. Een inleidende studie van Calvijn's Commentaar op Seneca. De Clementia, anno 1532 (1957) and also in the critical edition of the De Clementia (Leiden 1957) which he and Ford Lewis Battles edited. In his paper A Typology of "Schools" of Calvin Interpretation in 19th and 20th Century Theology Henry van der Goot agrees with Oberman as far as the Classical interpretation, the Neo-Orthodox and the Dutch, NeoCalvinistic Interpretation are concerned, but also suggests what he calls "Calvin 
the French Humanist"1, the "Liberal Interpretation" 2 and the Nationalist and Dialectical Interpretation ${ }^{3}$.

Due to the fact that there is a trend among some South African researchers to identify Calvin and Calvinism simplistically with the ideology of apartheid, it is essential for Calvin researchers in this country not only to have knowledge of the various schools of interpretation but also by means of their research and publications to prove the falseness of this theses and to put forward the real Calvin.

Therefore, in conclusion of this part of the article, which refers to general developments in Calvin research I would like to point to three remarks which J. Klempa made in the introduction to the Colloquium: "The Image of John Calvin in Recent Research." I do this because these remarks are, to my mind, also very relevant for Calvin research in Southern Africa, and for that matter for Calvin research in Africa.

* Firstly, he said:

We will not understand Calvin aright if at the outset we do not grasp something of his deep personal awareness of the directing and sustaining presence of the living God. ... Those who followed in his footsteps shared his attitude and thus were always a major force to contend with. Calvin sought to know God and to make God known (Klempa, 1987:344-345).

* Secondly he pointed out that Calvin's theology of a Duplex cognitio dei was not a closed system - on the contrary, Calvin preferred to combine a number of biblical and theological concepts in the socalled loci-method. With this approach he combined the rhetorical method, the result being that Calvin was not rigidly consistent in his use of the loci approach - some issues and questions he left unresolved (Klempa, 1987:345-346).

* Thirdly, Klempa remarked that Calvin's inestimable contribution to Protestantism was not only that he gave evangelical theology a dogmatic form but

I See for example the following works: John Calvin. A Study in French Humanism (Q Breen), The Social Humanism of John Calvin (A Bieler) and to a certain extent - Calvin The Origins and Development of his Religious Thought (F. Wcndel)

Sec for example Alexander Schweizer, FC. Baucr and Otto Ritschl as well as Max Weber, Protestant Ethic and the Spirit of Capitalism and E. Trocltsch, Social Teaching of the Christian Churches (2 vols) - the last two works representing the so called 'sociological' view within the Liberal Interpretation. Dialectical Interpretation' as put forward by Hernan Bauke in his book Die Probleme der Theologie Calvin's (1922). 
that he also connected it with the mainstream of the church's theological tradition. This point of view does not only account for the respectful attention of an increasing number of Roman Catholic scholars to his thought, but also for the persuasive power it exhibits, as well as for its connection with the dominant theological tradition and its ecumenical significance. During the course of the twentieth century Calvin's Institutes have been read by more and more scholars and many theological students have discovered the Institutes as a foundational source on which to base their initial theological training (Klempa, 1987:347).

The importance of studying the Institutes of course places a big responsibility on the shoulders of the Calvin researchers of our continent.

\section{Current trends in Calvin research}

A good indication of the most recent trends in Calvin research is the Calvin Bibliography, compiled by Peter de Klerk and published annually in the Calvin Theological Journal. In the 1991 issue De Klerk distinguishes seven main fields of interest in Calvin, some of them with extensive sub-divisions.

* Bibliographies.

* Calvin's works (works, selected works and selection of works).

* Calvin's life and work (biographies, commentaries on his writings, relation with Reformers, relation with others, his Humanism, his period in Switzerland and France).

* Calvins theology (Calvin's theology in general, the doctrine of God, the doctrine of man, the doctrine of Christ and salvation [Christology, grace, faith, Holy Spirit, justification, sanctification, Law-Gospel, predestination], the doctrine of church and sacrament [ecclesiology, apostolate, sacraments, baptism, Lord's Supper, eschatology]).

* Calvin's aesthetic, social-ethical and political views.

* Calvin's influence and

* Calvinism in general.

In his paper Current Trends in Calvin Research read at the 1990 Intemational Research Congress in Grand Rapids R. Gamble used distinctions which can largely be assimilated and integrated with those used by De Klerk. He, however adds one distinction which he calls "Calvin, Language and Hermeneutics" - a distinction of which he said in his paper: "It is in this ... area of recent Calvin research where, in my opinion, some of the greatest advances have been made and where much more research is needed" (Gamble, 1990:17). 


\title{
2.1 Bibliographies
}

Apart from the bibliographies as reported in the various issues of the annual Calvin Bibliography by Peter de Klerk two significant bibliographies should especially be mentioned. One of the bibliographies is written by the Dutch scholar W. de Greef: Johannes Calvijn zijn werk en geschriften (1989). This work has been called an indispensable introduction for anyone who wants to start with a study of Calvin. Detailed biographical information is given as well as elaborate registers and indications of sources which can help researchers further on the way. The other important publication is the 1991 edition of the first volume of Rodolphe Peter - Jean-Francois Gilmont's, Bibliotheca Calviniana. Les oeuvres de Jean Calvin publiées au XVIe siècle: I Ecrits théologiques, litteraires et juridiques 1532-1554 (1991). Regarding this volume De Boer (1992) writes in his review

\begin{abstract}
... it is a bibliography, a technical instrument. But it is also a collection of monographs. And at the same time it is a kind of biography. The history of the common cause and co-operation between the first author, his secretaries and his (often over-active) publishers is recorded here. It is the history of the man and his books, the instrument and effort which propelled the great sixteenth century Reformation of church and society.
\end{abstract}

In this field of research $A$ Bibliography of Calviniana 1959-1974 appeared in South Africa in 1975 (see Kempff, 1975). This bibliography was a publication of the then still functioning Institute for the Advancement of Calvinism. This bibliography which started where Niesel left off, was regarded as the first contribution of the I. A.C. towards international Calvin research. It remains a pity that this institute, which had been doing excellent work with this bibliography and which regarded the study of the original sources as of utmost importance, has had to scale down its work. Some kind of infrastructure for the co-ordination of Calvin and Reformation research needs to be established once again in South Africa.

\subsection{Calvin's life and work}

Particular fields of interest for scholars in this field of Calvin research have been a sociological and political interest in Calvin, exegetical history, biographies, Calvin and his environment and the role of language and hermeneutics with regard to Calvin research.

\subsubsection{Sociological and political interest}

There has lately been an upsurge of sociological interest in Calvin and Calvin studies. This interest has mainly been the result of the work of Robert M. Kingdon. 
Since 1962 he has been working on the Registers of the Company of Pastors. Together with this work Kingdon has also published a series of articles on social welfare in Calvin's Geneva as well as some articles on Post-Calvinian France (Kingdon, 1971, 1988(a)). Furthernore Kingdon has also presented papers at the International Calvin Research Congress on Calvinus Legislator: the 1543 'Constitution ' of the City of Geneva (Kingdon, 1988).

Apart from these articles by Kingdon other articles and books written from a sociological point of view have also been published. The following are worth mentioning: The Social History of the Reformation (Buck, s.a.); Calvinism and Social Welfare (Buck, 1982); Crime and Punishment in Calvin's Geneva, 1562 (Monter, 1973); Calvm and Social Welfare: Deacons and the Bourse française (Olson, 1988); Social Concern in Calvin's Geneva, (Innes, 1983) and John Calvin on the Diaconate and Liturgical Almsgiving (McKee, 1984). It is clear that much of this research has been done in an attempt to study Calvin against the background of his contemporary environment. This kind of research has to be done in order to outline the real Calvin. On the other hand it should always be remembered that in the end history is more than just the putting together of contemporary causes and results.

As regards the position of Calvin and politics, and specifically the relationship between church and state, research in this regard has been a perennial topic of discussion. "Much of the newer research in social history has impacted upon interpretation of the political situation in sixteenth century Geneva" (Gamble, 1990:3). It is interesting that in his article "Calvin and the Govenument of Geneva" Kingdon argues that the institution of eldership in Geneva was the result of an anticlerical revolution which began in 1535 when the first Protestants revolted against their bishop. This revolution was then carried further and completed by Calvin (Coertzen, 1991:331). That research in this regard is still continued is clear from the 1991 Bibliography of Peter de Klerk and also from a publication like that of Harow Höpfl, The Christian Piety of John Calvin (Hopfl, 1982).

In South Africa L.F. Schulze wrote on Calvin and 'Social Ethics'. His View on Property, Interest and Usury (Schulze, 1985). In 1990 Douglas S. Bax wrote on From (onstantine to Calvin: the Doctrine of the Just War. In 1990 L.F. Schulze wrote a series of articles "Hoe interpreteer ons Calvyn" (Schulze, 1990). In 1989 Johan Janse van Rensburg wrote an article in Die Kerkbode "Johannes Calvyn en menseregte". It is clear that South African researchers have kept themselves busy in this field of interest. The question however remains to which extent it amounted to original research from primary sources. 


\subsubsection{Exegetical history}

Regarding this field of Calvin research Gamble (1990) writes in his paper: "There has been a renaissance of interest in exegetical history, which is easily observable in the regular meetings of scholars at the University of Geneva to discuss sixteenth-century exegesis." Some of the most important scholars and publications in this field of study are the following: T.H.L. Parker "Calvin the Biblical Expositor" (Parker, 1964:23-31); Calvin the Exegete: Change and Development (Parker, 1987). David Steinmetz: John Calvin on Isaiah 6: A Problem in the History of Exegesis (Steinmetz, 1982). David Wright: Calvin's Penteteuchal Criticism (Wright, 1986). Susan Schreiner: "Through a Mirror Dimly: Calvin's Ser- . mons on Job" (Schreiner, 1986:175-193.) Irena Backus: Aristotelianism in Some of Calvin's and Beza's Expository and Exegetical Writings on the Doctrine of the Trinity with Particular Reference to the Terms "ousia" and "hypostasis" (Backus, 1987).

Particularly noteworthy in this regard are the books of T.H.L. Parker: Calvin's Old Testament Commentaries (Parker, 1986a); Calvin's New Testament Commentaries (Parker, 1971) and Commentaries on the Epistle to the Romans 15321542 (Parker, 1986b). Very significant work with regard to the way in which Calvin did exegesis was done by Alexander Ganoczy in conjunction with Stephan Scheld and Klaus Müller. In the publication Calvin's Handschrifiliche Annotationen zu Chrysostomos (Ganoczy et al., 1983) they conclude quite convincingly that Calvin was heavily indebted to the patristic father, St. John Chrysostom. Gamble views the monumental work of Ganoczy and Scheld Die Hermeneuttk Calvin's (Ganoczy \& Scheld, 1983) as one of the most significant works in exegetical history in the last decade or so. From their research on the hermeneutics of Calvin, Ganoczy and Scheld also produced Herrschaft - Tugend - Vorsehung (1982). Some other significant work in this field of exegetical history was done by Elsie Mckee in her two books John Calvin on the Diaconate and Liturgical Almsgiving (1984) and Elders and the Plural Ministry: The Role of Exegetical History in Illuminating John Calvin's Theology (1988).

Gamble (1990:5) concludes that the result of these studies have brought certain hallmarks to the fore.

First, in terms of the direction of Calvin Studies, more work has been put into Calvin's Old Testament commentaries recently than his new. Second, opinion is fairly solid that 'lucid brevity' or 'brevitas et facilitas' is the hallmark of Calvin's exegetical method. Thirdly the concept of accommodation has been demonstrated as integral to Calvin's method. Fourth, John Chrysostom has been proven to be a prime exegetical tutor to Calvin. 
One question which remains in this regard is whether there was any continuity of Calvin's exegetical method dating from his Seneca commentary to his biblical commentaries.

In the publication John Calvin and the Church. A Prism of Reform (George, 1990) one section is devoted completely to the interpretation of Holy Scripture with articles by George W. Stroup "Narrative in Calvin's Hermeneutic" (1990), Roland M. Frye, "Calvin's Theological Use of Figurative Language" (1990) and James Luther Mays, "Calvin's Commentary on the Psalms: The Preface as Introduction" (1990). This book, the result of colloquia on Calvin studies which convened on the campus of Davidson College, Davidson, North Carolina, presents itself as a part of the contemporary Christian church's rediscovery of Calvin as a formative influence on its own history and as a surprisingly relevant source in its efforts to live out "the faith once delivered unto the saints" during the last decade of the twentieth century" (George, 1990:11).

The only indication of work in this field of research which has been done in South Africa during the last twenty five years was an article by P.A. Verhoef "Luther and Calvin's Exegetical Library" (Verhoef, 1968:5-20). Cognisance should of course also be taken of the work of A M. Hugo: Calvijn en Seneca (Hugo, 1957).

\subsubsection{Biographies}

In his paper of 1990 Gamble did not specifically deal with biographies, although he did for instance mention and discuss the work of William Bouwsma in other respects. Biographies are a very significant aspect of Calvin research and some important work has been done in this field. Neuser is of opinion that a detailed study of the life of Calvin is of great necessity in our time. In recent times a great many shorter descriptions of the life of Calvin have appeared in print but a really extensive biography is still amiss - "een grote biografie ontbreek" (Neuser, 1990: 90). The deeper researchers probe into the theology of Calvin, the greater the need to understand his theology in view of his life. The following issues should be considered: What were the factors in his life which led to certain results and viewpoints in his theology? In which way did his theological viewpoints influence the times in which he lived?

Throughout the twentieth century significant biographies have appeared. The following biographies should be mentioned: E. Doumergue: Jean Calvin (18991927), reprinted by Slatkine, Geneva in 1970; Williston Walker: John Calvin Organizer of Reformed Protestantism (1906), W.F. Dankbaar: Calvijn, zijn weg en werk (1957), Jean Cardier: Calvin l'homme que Dieu a dompté (1958) Francois Wendel: Calvin, the Origins and Development of His Religious Thought, (published in French in 1950 by Presses Universitaires de France, and 
for the first time in an English translation in 1963. In 1965 it was issued for the first time in the Fontana Library with an eigth impression in June 1978 and an enlarged French edition in 1983). This biography is still considered by many to be one of the best on John Calvin. An important biography on Calvin which covers the period 1523-1539 is Alexander Ganoczy's Le Jeune Calvin. Genèse et evolution de sa vocation réformatrice (Ganoczy, 1966). Word has it that this work is to be translated in English. In his article "Recent Biographical Studies of Calvin" (Wolters, 1987:349-359) Wolters writes that the most significant biography to be produced in our time is that of T.H.L. Parker: John Calvin: A Biography, (Parker, 1975). This work supersedes his earlier brief introduction to Calvin, Portrait of Calvin (Parker, 1954). With sympathy towards Parker, Wolters however points out that the work has more the character of a theological assessment of Calvin than that of a biographical description

... it does not illumine the internal unity of Calvin's life in the context of his time. It is an insight gained by a theologian after long reflection on the significance of Calvin in the history of theological inquiry; it is not a pattern which can be shown to emerge out of the givens of Calvin's lifetime (Wolters, 1987:353).

One wonders to what extent Bouwsma has tried to correct this approach by Parker in his own work, John Calvin. A Sixteenth Century Portrait (1988). Another recent biography on Calvin is not a biography in the real sense of the word but an anthology of selected documents bearing on Calvin's life and thought. The volume was edited by G.R. Potter and M. Greengrass under the title John Calvin (Potter \& Greengrass, 1983). Wolters evaluates it as "a small, handy source-book which can serve as an excellent textbook in college history courses" (Wolters, 1987:354). The result of original research is the substantial and detailed study of Uwe Plath: Calvin und Basel in den Jahre 1552-1556 (Plath, 1974). The work is the result of many years of careful research in archives and brings to light many new connections and bits of information which bear directly on Calvins biography (Wolters, 1987:355). Two more biographies of a more popular nature have also been published during the last decade or so. From the pen of L. Janse we had Het Leven van Johannes Calvijn (Janse, 1980) and from the South African writer Jansie van der Walt Calvin and His Times was published (Van der Walt, 1988). Although characterizing the last mentioned biography as a popular biography, which is very sympathetic to its subject, Wolters is also of opinion that it is based on solid research (Wolters, 1987:351). Although it has, to my knowledge, not appeared in print I want to mention the paper which Heiko Oberman read at the 1990 Calvin Congress in Grand Rapids, Initia Calvini: The Matrix of Calvin's Reformation (Oberman, 1990). Apparently the paper is part of a thought provoking biographical study undertaken by Oberman. Researchers in South Africa will certainly have to take note of this. For Oberman the search for the historical Calvin is also very important and it is in this regard that he writes: 
Confronted with various claims of Calvin the Platonist, the Stoic, the Scotist, or the nominalist ... it is not too much to conclude that Calvin is caught in a true captivitatis systematica. What makes William J. Bouwsma's John Calvin. A Sixteenth Century Portrait the most significant biography since François Wendel is his quest for the historical Calvin, a man not of one system but a real human being exposed to a complex bundle of contradictory impulses (Oberman, 1990:13).

That Bouwsma's approach has not met with just approval is clear from reviews on the book which have been published. It however remains important for reseachers to take note of this publication.

One aspect in the Calvin biographies which continues to be highlighted is Calvin's conversion. The current discussion was mainly sparked off by the abovementioned work of Ganoczy which in its turn built on the earlier book by P. Sprenger, Das Ratsel um die Bekehrung Calvins (Sprenger, 1960). This debate has been reflected in South Africa with the publication of the article of W. Neuser, "Calvin's Conversion to Teachebleness" (Neuser, 1985:14-27).

\subsubsection{Calvin and his environment}

Major research has also been taking place during the past years with regard to Calvin and his environment i.e. with regard to the relationship between Calvin and late medieval theology, the relationship between Calvin and the Renaissance and Humanism and thirdly, the relationship between Calvin and his contemporaries.

Various scholars, like Alister E. McGrath, John Calvin and Late Medieval Thought (1986) and Late Medieval Theology and the Origins of the Reformed Church (1987), Thomas F. Torrance, The Hermeneutics of John Calvin (1988), Suzanne Selinger and David Steinmetz, Calvin and the Absolute Power of God (1988), have been engaged in studying the issue of Calvin's relationship to late medieval theology. In this endeavour they have made use of earlier work done by scholars such as Karl Reuter in Das Grundverständnis der Theologie Calvins. 1 could find no indication that any South African researcher has done any work in this field of research during the past few years.

A field of research which has received ample attention during the past years has been the relationship between Calvin, Renaissance and Humanism. At the 1986 Congress in Debrecen C. Augustijn states in his paper "Calvin und der Humanismus" the following: "Eine Reihe van Calvinforschern hat in den letzten Jahrzehnten das verhältnis Calvins zum Humanismus seiner Zeit studiert" (Augustijn, 1988:127ff.). Since that date work by authors such as McGrath, T.F. Torrance, and Bouwsma, which have been mentioned above, as well as the work of Mary 
Potter Engel, John Calvin's Perspectival Anthropology (Engel, 1988) and other works included in the De Klerk bibliography, have confirmed that this line of Calvin research is very much alive and well. An article by Bouwsma (1990:2841) "Calvin as Renaissance Artifact" in the above mentioned John Calvin and the Church. A Prism of Reform can also be mentioned in this regard. To a large extent the issue of the research is about what humanism is and whether Calvin can be categorized as a humanist. To answer these questions involves more than just an analysis of Calvin's exegetical method - a study of his anthropology and most probably of his epistomology should also be undertaken. With regard to this field of research Gamble (1990:14) concludes:

We are left, after eight years of further research and a number of articles, with no consensus. Nevertheless, a guide to further research in Calvin's relationship to humanism should follow certain rules: carefully defining terms; using the word 'humanism' self-consciously rather than haphazardly; analyzing humanism not exclusively from the vantage point of literary methodology but implementing current research and insights into Calvin's view of both history and humankind.

Two articles by B.J. van der Walt "The Intellectual Decor of the Reformation with Special Reference to Calvin" (Van der Walt, 1991a:201-208) and "Renaissance and Reformation Contemporaries but not Allies" (Van der Walt, 1991b: 209-256) confirm participation from South Africa in this debate.

As far as the relationship between Calvin and his contemporaries are concerned, there has also been continued interest in this topic during the last years. As far as his relationship with Luther and Erasmus is concerned it appears that there has been progress in the analysis of both Luther's and Erasmus's influence. Scholars who have contributed in this regard are among others Ganoczy and Scheld as well as Torrance and Engel. At the 1986 Congress Bishop Rogge read a paper on: "Themen Luthers im Denken Calvins" (Rogge, 1988:71). He concluded his paper with a citation from Peter Meinhold made in 1964 :

Calvin 'ergänzt ... in einer grossartigen Geschlossenheit ... das Werk Luthers nach mehr als einer Seite hin', bringt 'es recht eigentlich erst zu einer letzten Vollendung and Ausformung', die Luther 'auf Grund geschichtlicher Bedingtheiten nicht möglich gewesen ist'.

The strongest contemporary American proponent of Erasmus's influence on Calvin is William Bouwsma. He argues that the differences between Calvin and Erasmus are more of a temperamental than of a substantial nature.

He reminds us for example that the word Institutes as a book title had already been used by Erasmus. In many ways Ganoczy/ Scheld agree with this analysis: seeing in Erasmus many foundations for later Protestant exegesis (Gamble, 1990:15). 
A view contrary to this is put forward by T.F. Torrance who maintains that Calvin had a different epistomological foundation than Erasmus (in Gamble, 1990:1516).

With regard to other contemporaries much work has been done as can be seen in the De Klerk bibliographies of the past four years - one of the latest publications is the very well documented work of Marijn de Kroon Martin Bucer und Johannes Calvin Reformatorische Perspektiven Einleitung und Texte (De Kroon, 1991).

Although no South African contribution regarding Calvin's relationship with Erasmus and Luther could be found, a few articles appeared on Calvin's relationship with other contemporaries. I.L. de Villiers wrote on "Johannes Calvyn en die Franse lelie" (De Villiers, 1987:15), V.E. d'Assonville on "Observations on Calvin's Responsio to Cardinal Sadoletus's Letter to the Genevans" (D'Assonville, 1988:151-164) and Jansie van der Walt on "Servet en Calvyn" (Van der Walt, 1990).

\subsubsection{Calvin, language and hermeneutics}

Regarding language and hermeneutics Gamble (1990:17) states:

Some of the greatest advances have been made and where much more research is needed ... Research investigating Calvin and his environment has produced a re-examination of the philosophical/theological underpinnings of his thought and this re-examination has produced some new insights into the foundations of Calvin's language and epistomology.

Researchers on these issues include i.a. Bouwsma, Torrance and Selinger. At the moment Gilbert Vincent is the expert researcher in analizing Calvin's views on language and its impact on theology - cf. his book Exigence ethique et interpretation dans l'oeuvre de Calvin (Vincent, 1984) and his more recent article "La Rationalité herménetique du discours théologique de Calvin" (Vincent, 1987:133154). In this field reference can also be made to the interesting and well documented work of Paul C. Bottger Calvins Institutio als Erbauungsbuch. Versuch einer literarischen Analyse (Böttger, 1990).

Researchers such as Ganoczy/Scheld, Parker and Torrance are in harmony that Calvin had a different exegetical method as well as a different hermeneutic method as that of his contemporaries. The work which these researchers have done in this regard have paved the way for further research that has to be done in this respect. In South Africa 1 could establish one article which relates to the topic of Calvin's view on language and henneneutics - that of H.J. Schutte, H.W. Simpson and D. Breed "Calvyn se logika" (Schutte et al., 1990). 


\subsubsection{Calvins theology}

Much has been published on the theology of Calvin and related topics during the past few years. Anyone wanting to determine the extent of completed research topics available should consult the annual De Klerk bibliography. As far as the general trend of research is concerned, Gamble is of opinion that it largely rotates around the question of the structure of Calvin's theology and in this respect he states that "Calvin scholarship has shown increasing unanimity that the Duplex Cognitio Dei must be reckoned with as either $a$ controlling principle of his theology or the controlling principle" (Gamble, 1990:21). According to Gamble much of this unanimity in current scholarship on this issue stems from scholarly agreement on the foundations of Calvins epistomology itself.

Bouwsma made a considerable contribution to this last mentioned debate with his article "Calvin and the Renaissance Crisis of Knowing" (Bouwsma, 1982:190211). In 1987 Charles Partee on the other hand once again posed the question on "Calvin's Central Dogma again" (Partee, 1987:191-199). He argues in favour of a theologic rather than a philosophic approach to the theology of Calvin and is of opinion that such an approach is to be found in the doctrine of the union with Christ. In his article in the Dowey Festschrift Brian Armstrong also made a contribution to this debate - Armstrong stresses that the historical context should be brought more to the fore in the endeavour to find an answer to the question of whether or not the Duplex Cognitio Dei is $a$ or the fundamental principle of Calvin's thought.

There is no indication that the above-mentioned debate figures in any way in South African theology. Be it so or not, to my mind it remains important for researchers in this country to take note of the issues which are on the agenda of researchers elsewhere.

Regarding the work which has been done in South Africa on the theology of Calvin the following can be noted. A. le R du Plooy: "Die Dordtse leerreêls - ' $n$ belydenisskat uit die Refonmasie" (Du Plooy, 1989a:23-25, 1989b:29-30); J. du Preez: "John Calvin's Contribution to a Theologia Religionum" (Du Preez, 1988: 69-78); F.J.M. Potgieter: "Calvyn oor die predestinasie" (Potgieter, 1988: 396399); P. Coertzen: "Calvin's Influence on the Earlier Reformed Church Ordinances in the Netherlands" (Coertzen, 1988:173-193); A. Pont: "Die priesterskap van die gelowige soos Calvyn dit gesien het" (Pont, 1989a:451-464); B.J. van der Walt: "Sixteenth Century Models for Christian Involvement in the World" (Van der Walt, 1991c:159-199); P.A. Verhoef: "Calyyn oor Messiasverwagting in die Ou Testament" (Verhoef, 1990:112-117); John W. de Gruchy: "The Church always Reforming" (De Gruchy, 1990:154-185). 
Apart from these works the following South African contributions on the theology of Calvin have been made. P.H. Fick: Calvyn en Westphal: die ontwikkeling van 'n Nagmaalsleer (Fick, 1989); A.D. Pont: Die amp as dienswerk in die kerk (Pont, 1989b: 127-136); A.L. Rheeder: Die siel en liggaam by Calvyn en Plato: 'n vergelykende studie (Rheeder, 1989); C.S. Shim: An Evaluation of Calvin's Theological Position against the Libertines (Shim, 1988); C.F.A. Borchardt: "Luther en Calvyn oor die feilbaarheid van kerklike vergaderinge" (Borchardt, 1988:326-333); T.F.J. Dreyer: "Poging tot 'n herdefinisie van die prediking binne die raamwerk van die Reformatoriese teologie" (Dreyer, 1988:69-78); B.J. Engelbrecht: "Calvyn en die Calvinisme" (Engelbrecht, 1988:596-612); C.S. Kotze: "Calvyn oor kerk en amp" (Kotze, 1989:18-34); A.D. Pont: "Die sekerheid van geloof by Calvyn en sommige van sy navolgers" (Pont, 1988:404-419); M. Pretorius: "Calvyn se verklaring van die uitverkiesing" (Pretorius, 1989:6); J.H. van Wyk: "Besinning oor die twee-ryke leer" (Van Wyk, 1988:462-488).

The following South African theologians also made contributions on the theology of Calvin in the Festschrift für Wilhelm Neuser which was published in 1991: B.J. van der Walt: "The Idea of Reform"; J.J. Steenkamp: "A Review of the Concept of Progress in Calvin's Institutes"; P.C. Potgieter: "The Providence of God in Calvin's Correspondence"; A.D. Pont: "Confession of Faith in Calvin's Geneva"; P. Coertzen: "Presbyterial Church Government. Ius Divinum, Ius Ecclesiasticum or Ius Humanum?" and L.F. Schulze: "Totius as Psalmberymer."

Much more could be said about Calvin research at the moment. There is for instance the issue of Calvin's own works and also the influence of Calvin and Calvinism. With regard to Calvin's own works substantial work has been done in South Africa by Prof. Simpson with the Afrikaans translation of the Institutes.

That the question of Calvin's influence has enjoyed some attention from South African theologians is clear from the following publications: J.W. de Gruchy: "The Revitalization of Calvinism in South Africa: Some Reflections on Christian Belief, Theology, and Social Transformation" (De Gruchy, 1986:42, 47); André du Toit: "Puritans in Africa? Afrikaner Calvinism and Kuyperian Neo-Calvinism in Late Nineteenth-Century South Africa" (Du Toit, 1985:209-240); G.J. Schutte: "The Netherlands, Cradle of Apartheid?" (Schutte, 1987:392-414); D.J Bosch: "The Afrikaner and South Africa" (Bosch, 1986/87:203-216); J.W. de Gruchy: "Bonhoeffer, Calvinism and Christian Civil Disobedience in South Africa" (De Gruchy, 1981) and P. Coertzen: Vanaf Genève na die suidpunt van Afrika (Coertzen, 1989).

The above-mentioned researchers wanted to indicate some of the issues in Calvin research which have been addressed in our day as well as factors which have to be kept in mind when one attempts Calvin research. In some fields of research 
South African scholars have made a contribution with regard to research concerning current issues in Calvin research, in other areas, however, it must be stated that no research has come forth from South African scholars. It is important for South African researchers to stay abreast with Calvin research which is being done in other parts of the world and which is being addressed at international congresses. At the same time they will have to state the relevance of current Calvin research for South Africa today. Taking cognisance of the work of other researchers can benefit them. In this regard it can only be useful to take note of research needs which have already been identified.

\section{Research needs}

I would like to mention the following needs with regard to Calvin research:

* Much has been done with regard to the theology of Calvin, but much more needs to be done. Fields in which further research is necessary include inter alia the doctrine of justification and sanctification, Calvin's ecclesiology and his teachings on the offices in the church and also his exegesis.

* There is a definite need for a detailed analysis of the Institutes of Calvin, not

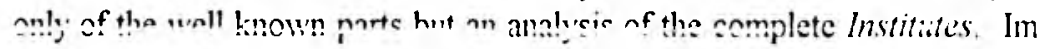
portant thoughts and themes in this regard have been neglected up to now.

* There is a need for a detailed biography on the life of Calvin.

* There is also a need for a new textcritical edition of the works of Calvin. Work in this regard is being done as it remains absolutely foundational for Calvin research.

* Historical and exegetical research of the life and writings of Calvin is another field of research which can be addressed by South African scholars.

* Neuser also mentions the need for a Calvin-Begriffslexikon (Neuser, 1990: 89-92).

Gamble concluded his paper in a last paragraph by writing "Calvin research continues to explode ... Nevertheless, further work needs to be done" (Gamble, 1990: 25).

\section{Research aids}

In conclusion I want to refer to the research aids for Calvin research which Neuser mentions in his paper on the future tasks of Calvin congresses.

Firstly he mentions the Annual Calvin Bibliography published since 1972 by Peter de Klerk. It is really to be hoped that this work will eventually be published 
in one volume. This work published annually in the Calvin Theological Journal is readily available in South Africa.

Secondly Neuser mentions the wordconcordance on the Institutes compiled by F.L. Battles. Unfortunately this work is only available on Microfiche and as far as I could establish it is not available in South African libraries. I understand a private copy is available in Potchefstroom. A new concordance, also on fiches and compiled by R.F. Wevers has also recently become available. In some way or other attempts should be made to make these works available to researchers in South Africa.

Thirdly Neuser also mentions the Concordance to the Latin Bible of John Calvin (6 vol.) also compiled by Wevers (Neuser, 1990:91-92).

\section{Calvin research in South Africa}

I would like to make a few suggestions concening future Calvin research and research congresses in South Africa:

* $\quad 1$ think it is necessary that each Calvin congress should appoint a steering committee taking responsibility together with a specific institution for the organizing of research congresses.

The steering committee can for instance submit proposals to the Congress with regard to a theme and papers for a next congress. In this way general developments in Calvin research will be taken into account and these developments can be accommodated within our own research community. To my mind this procedure will structure our Calvin research program - something which I think we need. Nobody encourages overorganization, but we need a more fixed structure if we want to develop a Calvin research program.

* Secondly I would like to suggest that thought be given to the possibility to let participants submit papers which they want to read at our congresses. The venue of a congress can be published worldwide. Maybe participants can then submit papers which the steering committee can consider, given the development of our research program. Perhaps such a method will open up our congress for researchers from other fields of theology and learning to participate. The steering committee can at the same time be given the freedom to invite certain scholars of standing which they deem necessary.

* Thirdly I would like to suggest that some form of report on the position of Calvin research, both national and international, should be read at every South African research congress. This procedure will most probably keep us informed about necessities that have to be addressed. 
* We have a very good relationship with the praesidium of the international congress. This relationship should be kept up and fostered - we definitely need the expertise of the praesidium and fellow researchers for our own research both in South Africa and abroad.

* Contact with the rest of Africa with regard to Calvin research must be sought and expanded.

* Students must be inspired to engage in Calvin research.

\section{Bibliography 4}

ANON. 1982. Calvinus Reformator. His Contribution to Theology, Church and Society. Potchefstroom : Potchefstroom University for Christian Higher Education.

AUGUSTIJN, C. 1988. Calvin und der Humanismus. (In Neuser, W. Calvinus Servus Christi. Budapest : Pressabteilung des Ráday-Kollegiums. p 127-142.)

COERTZEN, P. 1991. Presbyterial Church Government Ius Divinum, Ius Ecclesiasticum or Ius Humanum? (In Van't Spijker, W. red Calvin Erbe und Auftrag. Festschrift für Wilhelm Heinrich Neuser zum 65. Geburtstag. Kampen : Kok. p. 329-342.)

DE BOER, E.A. 1992. Unpublished response on paper given at 1992 Calvin Research Congress in Bloemfontein

DE GREEF, W 1989. Johannes Calvijn zijn werk en geschriften. Kampen : De Groot Goudriaan

DE KLERK, P. Calvin Bibliography 1988-1991. Calvin Theological Journal, 23(2) 1988; 24(2) 1989; 25(2) 1990, 26(2) 1991

GAMBLE, R 1990. A Review of "Eight Years of Calvin Research". Paper read at the International Calvin Research Congress, Grand Rapids 1990

GEORGE, T. 1990. John Calvin and the Church. A Prism of Reform. Louisville, Kentucky : Westminster/John Knox Press

HARRIS HARBISON, E. 1987 The Christian Scholar in the Age of the Reformation. New York: Charles Scribner's Sons. (Referred to in: Klempa, 1987:344.)

KLEMPA, W. 1987. Introduction: The Image of John Calvin in Recent Research. (In Furcha, E.J In Honor of John Calvin. Montreal : McGill University. p. 343-348.)

KEMPFF, D. 1975. A Bibliography of Calviniana 1959-1974. Potchefstroom : I A C.

NEUSER, W.H. 1976. Calvinus Theologus Die Referate des Europaischen Kongresses fur Calvinforschung. Neukirchen : Neukirchener Verlag

NEUSER, W.H. 1982. Calvin Ecclesiae Doctor Die Referate des Internationalen Kongresses für Calvinforschung. Kampen : Kok

NEUSER,W.H. 1984. Calvinus Ecclesiae Genevensis Custos Die Referate des Internationale Kongresses fur Calvinforschung. New York : Verlag Peter Lasng.

NEUSER, W.H. 1988. Calvinus Servus Christi. Die Referate des Internationalen Kongresses für Calvinforschung. Budapest : Pressabteilung des Ráday-Kollegiums.

4 Due to the nature of this specific article only works cited or directly consulted by the author are included in the bibliography. The bibliographic details of works which have only been referred to as belonging to the general body of Calvin rescarch, and on which bibliographic information could be found, are included in a separate list of references. 
NEUSER, W.H. 1990. Het werk van de Calvijncongressen en hun toekomstige taken en doelen. (In De Greef, W. \& Van Campen M. reds. Reformatie-Studies, Congresbundel 1989. Kampen : De Groot Goudriaan. p. 87-92.)

OBERMAN, H 1986. Calvin's Critique of Calvinism. (In Oberman, H. The Dawn of the Reformation. Essays in Late Medieval and Early Reformation Thought. Edinburgh : T\& T Clark. p 259-268.)

PONT, A. ed. 1990. Calvin-France-South Africa Pretoria: Kital.

PRAAMSMA, L. 1981. De kerk van alle tijden. Verkenningen in het landschap van de Kerkgeschiedenis, deel 4. Franeker: T. Wever.

SCHILDER, K 1981 Tussen "Ja" en "Nee". (In Praamsma, L. Die kerk van alle tijden. Verkenningen in het landschap van de kerkgeschiedenis, deel 4. Franeker : Wever. p. 69.)

VAN DER GOOT, H 1975 A Typology of "Schools" of Calvin Interpretation in the 19th and 20th century Theology. Typed copy of a paper prepared by Van der Goot in 1975

VAN'T SPIJKER, W. 1991 Calvin Erbe und Auftrag. Festschrift für Wilhelm Heinrich Neuser zum 65. Geburtstag Kampen: Kok.

WOLTERS, A. 1987 Recent Biographical Studies of Calvin (In Furcha, E.J. In Honor of John Calvin, 1509-1564. Montreal : Mcgill University. p 349-360.)

\section{Additional works only referred to in the text}

BACKUS, I 1987 Aristotelianism in Some of Calvin's and Beza's Expository and Exegetical Writings on the Doctrine of the Trinity with Particular Reference to the Terms "ousia" and "hypostasis". (In Fatio, O. \& Fraenkel, P. eds. Histoire del'exegèse au XVIe siècle Genève : Librairie Droz p. 351-360)

BARTH, P 1936. Das Problem der Naturlichen Theologie bei Calvin Munich

BAX, D S. 1990. From Constantine to Calvin: The Doctrine of the Just War (In Villa-Vincencio, C ed. Theology \& Violence. The South African Debate Grand Rapids Wm B. Eerdmans Publishing Co p. 147-171)

BORCHARDT, C F A 1988. Luther en Calvyn oor die feilbaarheid van kerklike vergaderinge. Nederduitse Gereformeerde Teologiese Tydskrif, 29(4):326-333

BOSCH, D J 1986/87. The Afrikaner and South Africa. Theology Today, 43:203-216

BOTTGER, P.C. 1990. Calvins Institutio als Erbauungsbuch Versuch einer literarischen Analyse Neukirchen : Neukirchener Verlag

BOUWSMA, W J. 1982. Calvin and the Renaissance Crisis of Knowing. Calvin Theological Journal, 17:190-211, Nov.

BOUWSMA, W. J. 1989 John Calvin. A Sixteenth Century Portrait_ New Yourk : Oxford University Press

BOUWSMA, W.J 1990. Calvin as Renaissance Artifact (In George, T. John Calvin and the Church A Prism of Reform. Westminster/John Knox Press : Louisville, Kentucky. p 28-41)

BUCK, L P s a. The Social History of the Reformation. Ed. by Laurence P Buck and Jonathan W. Zophy

BUCK, L P. 1982. Calvinism and Social Welfare. Calin Theological Journal, 17.212-230

COERTZEN, P 1988. Calvin's Influence on the Earlier Reformed Church Ordinances in the Netherlands. (In Neuser, W. Calvinus Servus Christi. Budapest : Pressabteilung des Ráday-Kollegiums. p 173-193.)

COERTZEN, P 1989 Vanaf Genève na die suidpunt van Afrika Kaapstad : N.G Kerkuitgewers 
D'ASSONVILLE, V.E. 1988. Observations on Calvin's Responsio to Cardinal Sadoletus's Letter to the Genevans. (In Neuser, W. Calvinus Servus Christi, Budapest : Pressabteilung des Ráday-Kollegiums p. 151-164.)

DE GREEF, W. 1989 Johannes Calvijn zijn werk en geschriften. Kampen : De Groot Goudriaan.

DE GRUCHY, JW. 1981. Bonhoeffer, Calvinism and Christian Civil Disobedience in South Africa Scottish Journal of Theology, 34:245-262

DE GRUCHY, J.W. 1986. The Revitalization of Calvinism in South Africa: Some Reflections on Christian Belief, Theology, and Social Transformation. The Journal of Religious Ethics, 14:22-47.

DE GRUCHY, J.W 1990. - The Church always Reforming. The Princeton Seminary Bulletin, 12:154-185.

DE KROON, M 1991. Martin Bucer und Johannes Calvin. Reformatorische Perspektiven Einleitung und Texte. Aus dem Niederländisch überzetzt von Hartmut Rudolph Gottingen : Vandenhoeck \& Ruprecht

DE VILLIERS, I.L 1987. Johannes Calvyn en die Franse lelie. Die Kerkbode, 140:15, Okt 14.

DREYER, T.F.J. 1988. Poging tot 'n herdefinisie van die prediking binne die raamwerk van die Reformatoriese teologie. Hervormde Teologiese Studies, 45(2):69-78.

DU TOIT, A. 1985. Puritans in Africa? Afrikaner Calvinism and Kuyperian Neo-Calvinism in Late Nineteenth-Century South Africa. Comparative Studies in Society and History, 27 : 209-240

DU PLOOY, A le R 1989a Die Dordtse leerreels - 'n belydenisskat uit die Reformasie Die Kerkblad, 91:23, 25, Maart 8.

DU PLOOY, A le R. 1989b. Die Dordtse leerreels - 'n belydenisskat uit die Reformasie. Die Kerkblad, 91:29-30, Maart 22

DU PREEZ, J 1988. John Calvin's Contribution to a Theologia Religionum Missionalia, 16:69-78.

ENGELBRECHT, B J 1988 Calvyn en die Calvinisme Hen'ormde Teologiese Studies, 44 : 596-612

ENGEL, M.P. 1988. John Calvin's Perspectival Anthropology. American Academy of Religion Series: 52 [Atlanta, GA: Scholars Press]

FICK, P.H. 1989. Calvyn en Westphal die ontwikkeling van 'n nagmaalsleer. Pretoria : UP. (Thesis.)

FRYE, R.M 1990. Calvin's Theological Use of Figurative Language. (In George, Timothy. ed John Calvin and the Church. A Prism of Reform Louisville, Kentucky: Westminster/John Knox Press. p. 172-194.)

GANOCZY, A. 1966. Le Jeune Calvin. Genèse et evolution de sa vocation réformatrice Wiesbach : Franz Steiner.

GANOCZY, A. \& SCHELD, S 1982 Herrschaft-Tugend-Vorsehung Wiesbaden : Steiner

GANOCZY, A., SCHELD, S \& MULLER, K 1983 Calvin's Handschriftliche Annotationen zu Chrysostomos. Wiesbaden : Steiner.

GANOCZY, A \& SCHELD, S 1983 Die Hermeneutik Calvin's Wiesbaden: Steiner

GILMONT, JF. 1991. Bibliotheca Calviniana Les oeuvres de Jean Calvin publiẻes au XVIe siécle: I Ecrits théologiques, litteraires et juridiques 1532-1554 Genéve : Droz

HÖPFL, H 1982. The Christian Piety of John Calvin. Cambridge : Cambridge University Press.

HUGO, A M 1957. Calvijn en Seneca. Een inleidende studie van Calvijn's Commentaar op Seneca, De Clementia, anno 1532. Groningen : Djakarta 
INNES, W. 1983 Social Concern in Calvin's Geneva Allison Park, Pa : Pickwick Publications.

JANSE, L. 1980 Het leven van Johannes Calvijn. Kampen : Kok.

JANSE VAN RENSBURG, J.J. 1989. Johannes Calvyn en menseregte Die Kerkbode, 144, Des. 1

KINGDON, R 1971. Social Welfare in Calvin's Geneva. American Historical Revew, 76 : 50-69.

KINGDON, R 1988a. Myths about the St Bartholomew's Day Massacres 1572-1576, Cambridge : Harvard University Press

KINGDON, R 1988b Calvinus Legislator: the 1543 'Constitution' of the City of Geneva ( $n$ Neuser, W ed Calvinus servus Christi Budapest : Pressabteilung des Ráday-Kollegiums.)

KOTZE, C S. 1989. Calvyn oor kerk en amp. Studia Hisioriae Ecclesiasticae, 15(1)18-34.

LANGHOFF, J \& ROGGE, J 1984 Immigration und Emigration - die calvinistische Einwanderung und Auswanderung in Mitteleuropa. Beitrage des II Kongresses für Calvinforschung in Mittel- und Osteuropa 1984 Edited by J Langhoff and J. Rogge.

MAYS, J L. 1990. Calvin's Commentary on the Psalms: The Preface as Introduction (In George, Timothy ed John Calvin and the Church. A Prism of Reform Louisville, Kentucky : Westminster/John Knox Press p. 195-204)

MCKEE, E 1984. John Calvin on the Diaconate and Liturgical Almsgiving. Geneva . Librairie Droz

MCKEE, E 1988. Elders and the Plural Ministry The Role of Exegetical History in Illuminating John Calvin's Theology Geneva : Librairie Droz.

MONTER, E W. 1973 Crime and Punishment in Calvin's Geneva, 1562. Archiv fur Reformationsgeschichte, 64:281-287

NEUSER, W. 1985 Calvin's Conversion to Teachebleness. Nederdinitse Gereformeerde Teologiesc Tydskrif, 26:14-27

OLSON, J. 1988. Calvin and Social Welfare Deacons and the Bourse française Selinsgrove. PA: Susquehanna University Press and London : Associated University Presses.

OBERMAN, H 1986. Calvin's Critique of Calvinism (lm Obermann, Heiko The Dawn of the Reformation Edinburgh T \& T Clark pp 259-268.)

PARKER, T.H.L. 1954. Portrait of Calvin London: SCM

PARKER, T H.L. 1964 Calvin the Biblical Expositor. The (hurchman, 78 23-31.

PARKER, T.H.L. 1971. Calvin's New Testament Commentaries Grand Rapids : Eerdmans

PARKER, T.HL. 1975. John Calvin: A Biography London and Philadelphia

PARKER, T.H.L. 1986a Calvin's Old Testament Commentaries Edinburgh : T\&T Clark

PARKER, TH.L. 1986b Commentaries on the Epistle to the Romans 1532-1542 Edinburgh T\&T Clark

PARKER, THL. 1987. Calvin the Exegete: Change and Development (In Neuser, W. ed. Calvinus Ecclcsiae Doctor Kampen Kok)

PARTEE, C. 1987. Calvin's Central Dogma Again The Sixteenth Century Journal, 18 191199

PLATH, U. 1974 Calvin und Basel in den Jahre 1552-1556 Zurich.

PONT, A D 1988 Die sekerheid van geloof by Calvyn en sommige van sy navolgers. Hervormde Teologiese Studies, 44(2) 404-419.

PONT, A 1989a. Die priesterskap van die gelowige soos Calvyn dit gesien het. Henormde Teologiese Studies, 45:451-460

PONT, A 1989b Die amp as dienswerk in die kerk (In Du Rand, J A \& Kellerman, J S reds. Diensknegte van die Koning. Huldigingsbundel ter ere van proff J J de Klerk en E.P J Kleynhans Bloemfontein : Pro-Christo Publikasies pp 127-136) 
PONT, A. 1991. Confession of Faith in Calvin's Geneva. (In van 't Spijker, W. red. Calvin. Erbe und Auftrag. Festschrift fur Wilhelm Heinrich Neuser zum 65 Geburtstag Kampen : Kok. p. 106-116.)

POTGIETER, F.J.M. 1988. Calvyn oor die predestinasie. Die Nederdhits Gereformeerde Teologiese Tydskrif. 29:396-399.

POTGIETER, P.C. 1991. The Providence of God in Calvin's Correspondence. (In Van 't Spijker, W. red Calvin. Erbe und Auftrag. Festschrift für Wilhelm Heinrich Neuser zum 65 Geburtstag. Kampen : Kok p. 85-94.)

POTTER, GR \& GREENGRASS, M. 1983. John Calvin (in the series Documents of Modem History New York

PRETORIUS, M. 1989 Calvyn se verklaring van die uitverkiesing. Die Boodskapper, 24 6, Okt

RHEEDER, A.L. 1989. Die siel en liggaam by Calvyn en Plato: 'n vergelykende studie Pretoria : UP (ThM-verhandeling.)

ROGGE, J. 1988. Themen Luthers im Denken Calvins (In Neuser, W Calvinus servus Christi. Budapest : Pressabteilung des Ráday-Kollegiums p 53-71)

SHIM, C.S. 1988. An Evaluation of Calvin's Theological Position against the Libertines Pretoria : UP. (ThD-Thesis.)

SCHREINER, S 1986 Through a Mirror Dimly: Calvin's Sermons on Job. Calvin Theological Journal, $21: 175-193$.

SCHULZE, L.F. 1985. Calvin and "Social Ethics". His View on Property, Interest and Usury. Pretoria : Kital

SCHULZE, L.F. 1990. Hoe interpreteer ons Calvyn. Die Kerkblad, 93 Nov. 7, Nov. 21, Des. 5, Des 19, Jan. 16

SCHULZE, LF. 1991. Totius as Psalmberymer (In Van't Spijker, W. Calvin. Erbe und Auftrag. Festschrift furr Wilhelm Heinrich Neuser zum 65. Geburtstag. Herausgegeben von Willem van 't Spijker. Kampen : Kok p 379-390)

SCHUTTE, G.J. 1987. The Netherlands, Cradle of Apartheid? Ethmic and Racial Studies, 10:392-414

SCHUTTE, H J., SIMPSON, HW \& BREED, D 1990. Calvyn se logika. Die Kerkblad, Feb. 21, Maart 21, April 4

SPRENGER, P. 1960. Das Ratsel um die Bekehrung Calvins Neukirchen: Neukirchener Verlag.

STEENKAMP, A. 1991. Review of the Concept of Progress in Calvin's Institutes ( $I n$ Van 't Spijker, W red. Calvin Erbe und Auftrag Festschrift für Wilhelm Heinrich Neuser zum 65. Geburtstag. Kampen : Kok -p 69-76)

STEINMETZ, D 1982. John Calvin on Isaiah 6: A Problem in the History of Exegesis Interpretation, 36:156-170.

STROUP, G.W. 1990 Narrative in Calvin's Hermeneutic (In George, Timothy ed. John Calvin and the Church. A Prism of Reform Louisville, Kentucky : Westminster/John Knox Press p 158-171)

VAN DER WALT, B J 1991a. The Intellectual Decor of the Reformation with Special Reference to Calvin. (In Anatomy of Reformation. Flashes and Fragments of a Reformational Worldview. Wetenskaplike Bydraes of the Potchefstroom University for Christian Higher Education, Series F: Institute for Reformational Studies. F3: Collections, 13 Potchefstroom : Potchefstroom University for Christian Higher Education. pp 201-208 Also in the 1981 edition of Anatomy of Reformation pp 154-163.) 
VAN DER WALT, B.J 1991b. Renaissance and Reformation Contemporaries but not Allies (In Anatomy of Reformation. Flashes and Fragments of a Reformational Worldview. Wetenskaplike Bydraes of the Potchefstroom University for Christian Higher Education, Series F: Institute for Reformational Studies. F3: Collections, 13. Potchefstroom : Potchefstroom University for Christian Higher Education. pp. 209-256. Also in the 1981 edition of Analomy of Reformation pp 164-214)

VAN DER WALT, B. 1991c. Sixteenth Century Models for Christian Involvement in the World (In Anatomy of Reformation. Flashes and Fragments of a Reformational Worldview. Wetenskaplike Bydraes of the Potchefstroom University for Christian Higher Education. Series F: Institute for Reformational Studies. F3 Collection, 13. Potchefstroom PU for CHE. pp. 159-199.)

VAN DER WALT, B.J. 199ld. The Idea of Reform. (In Van 't Spijker, W. red Calvin. Erbe und Auftrag Festschrift für Wilhelm Heinrich Neuser zum 65. Geburtstag Kampen: Kok p 18-30.)

VAN DER WALT, J 1988. Calvin and His Times. Potchefstroom

VAN DER WALT, J. 1990. Servet en Calvyn Die Kerkblad, 93, Mei 23, Junie 6, Junie 20.

VAN WYK, J.H. 1988 Besinning oor die twee-ryke leer Henormde Teologiese Studies, 44(2):462-488.

VERHOEF, P.A. 1968. Luther and Calvin's Exegetical Library. Calvin Theological Journal, 3:5-20.

VERHOEF, P.A. 1990. Calvyn oor Messiasverwagting in die Ou Testament Koers, 55:112117.

VINCENT, G. 1984. Exigence ethique et interpretation dans l'oeuvre de Calvin Geneva Labor et Fides.

VINCENT, G 1987. La Rationalité herménetique du discours théologique de Calvin. Archives de Sciences Sociales des Religions, 63:133-154

WRIGHT, D 1986. Calvin's Penteteuchal Criticism Calvin Theological Journal, 21:33-50. 
